\title{
HUBUNGAN PENGGUNAAN BACKPACK DAN POSISI DUDUK TERHADAP KELUHAN NYERI PUNGGUNG PADA ANAK USIA SEKOLAH
}

\author{
Chyntia Utami $^{1}$, Abdurrahman Hamid ${ }^{2}$, Yecy Anggreny ${ }^{3}$ \\ 1,2,3 Program Studi Keperawatan STIKes Hangtuah Pekanbaru \\ Email: Chyintiautami15@gmail.com
}

\begin{abstract}
Abstrak
Penggunaan backpack dan posisi duduk merupakan bagian dari keseharian anak usia sekolah. Jika penggunaan backpack tidak sesuai dan posisi duduk tidak ergonomis, maka hal ini menjadi pencetus terjadinya nyeri punggung pada anak usia sekolah. Penelitian ini bertujuan untuk mengetahui hubungan penggunaan backpack dan posisi duduk terhadap keluhan nyeri punggung pada anak usia sekolah. Penelitian ini merupakan penelitian kuantitatif dengan pendekatan cross sectional. Sampel pada penelitian ini berjumlah 121 anak usia sekolah di SD Negeri 111 Kota Pekanbaru. Pengambilan sampel pada penelitian ini menggunakan teknik stratified random sampling. Pengambilan data dilakukan menggunakan kuisioner penggunaan backpack dan lembar observasi REBA (Rapid Entire Body Assesment). Penelitian ini menggunakan analisis bivariat yaitu uji Chi-Square. Hasil penelitian menunjukkan, dari 121 siswa, dijumpai 97 siswa $(80,2 \%)$ mengeluh nyeri punggung ringan. Nyeri ringan banyak dikeluhkan oleh siswa dengan penggunaan backpack yang tidak sesuai sebanyak 78 siswa $(86,7 \%)$, dan siswa dengan posisi duduk yang kurang ergonomis sebanyak 58 siswa $(80,6 \%)$. Terdapat hubungan antara penggunaan backpack dengan keluhan nyeri punggung dengan $P$ value $0,011(\mathrm{P}<0,05)$, dan terdapat hubungan antara posisi duduk dengan keluhan nyeri punggung dengan $P$ value $0,042(\mathrm{P}<0,05)$ pada siswa kelas 4 dan 5 SD Negeri 111 Kota Pekanbaru. Kesadaran untuk memperhatikan tata cara penggunaan backpack dan posisi duduk anak di sekolah penting untuk diterapkan sebagai upaya pencegahan guna menurunkan timbulnya keluhan nyeri punggung pada anak usia sekolah.
\end{abstract}

Kata Kunci : Anak Usia Sekolah, Nyeri Punggung, Penggunaan Backpack, Posisi Duduk.

\begin{abstract}
Carrying backpack and sitting position are parts on school age children's daily life. Carrying unsuitable backpack and sitting in less-ergonomic position can cause back pain on schoolchildren. This study was aimed at determining correlation between carrying backpack and sitting position and complaints of back pain on school age children. A cross sectional study was undertaken among 121 school age children at 111 Public Elementary School, Pekanbaru. Stratified random sampling technique was applied to select the samples for this study. Data were collected using questionnaire on wearing backpack and REBA (Rapid Entire Body Assessment) observation sheet. Data analysis was conducted using bivariate test with Chisquare test. The result of this study showed that of all 121 students observed, 97 of them (80.2\%) complained of mild backpain. The complaints of mild back pain mostly came from respondents carrying unsuitable backpack with 78 respondents (86.7\%) and from those of with less ergonomic sitting position with 58 respondents (80.6\%). There was a correlation between carrying backpack and complaints of back pain with $P$ value 0.011 $(P<0.05)$, and there was a correlation between sitting position and complaints of back pain with $P$ value $0.042(P<0.05)$ on $4^{\text {th }}$ and $5^{\text {th }}$ grade students of 111 Public Elementary School, Pekanbaru. Awareness to pay more attention toward how to carry backpack as well as sitting position is extremely important to be implemented in order to prevent complaints on back pain on schoolchildren.
\end{abstract}

Keywords : Back pain, Carrying backpack, Schoolchildren, Sitting position 
Chyntia Utami, Abdurrahman Hamid, Yecy Anggreny, Hubungan Penggunaan Backpack dan Posisi Duduk terhadap Keluhan Nyeri Punggung pada Anak Usia Sekolah

PENDAHULUAN

Anak usia sekolah dimulai dari periode umur 6-12 tahun. Dikatakan usia sekolah, karena pada periode ini dimulai dengan masuknya anak ke lingkungan sekolah, yang berdampak bagi perkembangan dan hubungan anak dengan orang lain (Wong, Hockenbery,Wilson,Winkelstein, \& Schwantz, 2009). Anak usia sekolah dasar dimulai dari periode kelas rendah (6-9 tahun), dan periode kelas tinggi (10-12 tahun) (Depkes RI, 2009). Pada anak usia sekolah, perkembangan terjadi secara bertahap, yang ditandai dengan perkembangan lebih besar pada aspek fisik dan emosional (Wong.,et.al, 2009).

Periode anak usia sekolah memiliki angka persebaran yang cukup besar di dunia. Berdasarkan data dari United Nations Educational, Scientific, and Cultural Organization (2019) memberikan kesimpulan data bahwa anak usia sekolah di dunia pada tahun 2017 berjumlah lebih dari 716 juta jiwa, dengan jumlah siswa laki-laki lebih dari 370 juta jiwa, dan siswa perempuan lebih dari 346 juta jiwa. Di Indonesia jumlah anak usia sekolah dasar pada tahun 2018 berkisar 28,3 juta jiwa dengan anak usia di bawah 7 tahun berjumlah 2,35 juta jiwa, umur 7-12 tahun sebanyak 22,5 juta jiwa, dan jumlah anak usia di atas 12 tahun ialah 666 ribu jiwa, dan di provinsi Riau anak usia sekolah berjumlah 137 ribu jiwa (Kementerian Pendidikan dan Kebudayaan, 2017).
Sebelum mencapai fase pubertas, proses osifikasi pada anak usia sekolah terus tumbuh dan menguat, akan tetapi tulang tersebut bersifat rapuh dan mudah luka. Namun, seiring dengan bertumbuhnya tulang, fungsi otot pada anak usia masih belum mature dibanding dengan anak remaja (Kozier., et.al, 2011). Anak usia sekolah memiliki lebih dari 600 otot yang berkembang seiring dengan pertambahan tinggi dan berat badan pada anak. Otot- otot yang belum matang ini berfungsi untuk membantu anak dalam melakukan aktivitas seperti berlari, melompat, dan membawa ransel yang penuh dengan buku (Bryant, 2019). Sehingga, anak usia sekolah memiliki kerentanan untuk mengalami permasalahan otot akibat dari penggunaan yang berlebihan seperti spondylolysis, dislokasi segmen tulang belakang, dan ketegangan pada otot tulang belakang (Rai.,et.al, 2013). Hal-hal tersebut di atas dapat dijadikan sebagai upaya preventif orang tua dalam mendeteksi secara dini perhambatan pertumbuhan pada anak usia sekolah yang meningkatkan kerentanan anak terhadap berbagai penyakit (Kozier., et.al, 2011).

Anak usia sekolah juga memiliki kerentanan terhadap penyakit yang diakibatkan oleh aktivitas fisik, karena disamping konsistensi pada pertumbuhan dan perkembangan, anak juga memiliki tugas perkembangan yang wajib dicapai yaitu 
peningkatan keterampilan dalam aktivitas fisik, dan olahraga yang membutuhkan hiperekstensi tulang belakang berulang (Kozier., et. al, 2011), yang menyebabkan cidera pada jaringan lunak, tulang, maupun saraf, yang berakibat terhadap keluhan nyeri punggung yang dirasakan oleh anak (Azabegic, Spahic, Pranjic, \& Mulic, 2016).

Nyeri punggung adalah salah satu keluhan muskuloskeletal yang pernah dirasakan oleh setiap individu di sepanjang kehidupan. Nyeri punggung merupakan suatu gejala, bukan sebuah diagnosa (Walker, 2012). Rasa nyeri yang berbeda didapati pada nyeri punggung yang dirasakan oleh anak dan orang dewasa. Terlebih, jika nyeri punggung yang diderita anak disertai dengan keluhan lain, seperti demam, penurunan berat badan, kelemahan, kebas, masalah ketika berjalan, nyeri yang menyebar ke tungkai bawah, kandung kemih dan usus yang bermasalah, serta nyeri yang dapat mengganggu tidur anak (American Academy Of Orthopedic Surgeons, 2015).

Penelitian yang dilakukan oleh Azabagic., et.al (2016) anak usia 8-12 tahun di Tuzla Canton menunjukkan hasil bahwa 624 anak (48\%) merasakan nyeri muskuloskeletal, dan 214 anak dengan persentase 16\% merasakan nyeri punggung kronik. Studi lain menunjukkan bahwa prevalensi dari nyeri punggung bawah pada anak usia sekolah berkisar antara 25\%- 55\% pada umur 10 sampai 15 tahun (Macedo, Silva, Sousa.,et.al,
(2015); Wirth, Knecht, Humphreys, (2013)). Pernyataan di atas juga diperjelas oleh studi yang dilakukan oleh Spiteri, Busuttil, Aquilina., et.al (2017) pada anak usia 8-13 th. Dari 4005 partisipan, didapati $74 \%$ partisipan mengeluh nyeri pungung ringan, dan $25 \%$ nyeri punggung dirasakan oleh anak yang berusia 8-9 tahun. Allghamdi, Nafee, ElSayed, dan Alsaadi (2018) melakukan sebuah studi penelitian di kota Damam City, Arab Saudi dengan hasil bahwa 96,3\% siswa membawa tas backpack lebih dari 15\% Indeks Massa Tubuh mereka ke sekolah, 25\% siswa mengalami low back pain, 40,0\% nyeri pada bahu, dan $36 \%$ merasakan nyeri kepala. Di Indonesia, dan di Riau belum ada data dan survei spesifik mengenai nyeri punggung pada anak. Hal ini sesuai dengan studi awal yang dilakukan oleh peneliti, berdasarkan keterangan dari Dinkes Kota Pekanbaru belum ada data yang menunjukkan prevalensi nyeri punggung pada anak usia sekolah. Studi awal yang dilakukan peneliti ke bagian UKS puskesmas Sidomulyo, Pekanbaru, di ketahui bahwa tidak ada pemeriksaan ke sekolah dasar yang berhubungan dengan penggunaan backpack, seperti pengukuran terhadap berat tas yang dibawa anak, dan tata cara penggunaan backpack yang benar. Pihak puskesmas juga menjelaskan bahwa selama ini tidak ada pemeriksaan terhadap posisi duduk anak di dalam kelas.

Backpack atau tas ransel merupakan bagian yang tidak terpisahkan dari anak usia 
Chyntia Utami, Abdurrahman Hamid, Yecy Anggreny, Hubungan Penggunaan Backpack dan Posisi Duduk terhadap Keluhan Nyeri Punggung pada Anak Usia Sekolah

sekolah. Backpack digunakan untuk menyimpan dan membawa barang keperluan sekolah dari rumah ke sekolah, dan sebaliknya. Pernyataan ini juga diperkuat dengan pendapat yang dikemukakan oleh American Chiropatic Association (ACA) dalam Alghamdi.,et.al (2018) bahwa penyebab paling umum dari nyeri punggung yang dirasakan anak-anak ialah keseleo dan ketegangan otot yang terjadi karena membawa ransel yang berat. Ransel dengan beban yang berat juga menyebabkan tekanan pada diskus (disc) yang berfungsi sebagai bantalan antar tulang pada tulang belakang (Warner, 2010), karena pada anak usia sekolah berat backpack yang dibawa setiap hari tidak boleh lebih dari $10 \%$ Indeks Massa Tubuh anak dan tas yang topang oleh punggung tidak lebih dari 4 inci dibawah panggul anak usia sekolah (The American Occupational Therapy Association (2017).

Bagian kedua yang menjadi penyebab dari nyeri punggung pada anak usia sekolah ialah posisi duduk, karena anak menghabiskan hampir sebagian waktu mereka dalam posisi duduk, terutama saat proses belajar mengajar di dalam kelas. Seharusnya, posisi duduk yang ideal ialah duduk dengan kemiringan $135^{\circ}$, dimana posisi ini menempatkan tulang belakang bagian bawah berbentuk "S", memudahkan manusia untuk bergerak dengan baik, memudahkan pergerakan di atas kursi, serta memudahkan untuk naik atau turun dari kursi. Namun, mayoritas individu terbiasa untuk duduk dengan posisi yang tidak seimbang, yaitu duduk dengan sudut $90^{\circ}$. Duduk dengan posisi demikian berakibat pada pergerakan sendi tulang belakang, yang menjadi pencetus timbulnya keluhan nyeri punggung (Asriwati, 2017).

Studi awal yang dilakukan oleh peneliti pada 10 anak di Sekolah Dasar Negeri 111 Kota Pekanbaru dengan wawancara, didapati hasil bahwa 7 orang anak merasakan nyeri punggung, sedangkan 3 anak tidak merasakan nyeri. Dalam wawancara yang dilakukan, peneliti memberi 7 pertanyaan yang sama dengan kesimpulan, 10 anak tersebut ke sekolah menggunakan backpack dan duduk di dalam kelas dengan posisi yang tidak ergonomis. Berdasarkan observasi yang dilakukan, tidak terdapat loker di setiap kelas, dan tidak ada kontrol dari pihak sekolah terhadap beban backpack yang dibawa anak dan posisi duduk anak saat proses belajar mengajar di sekolah. Berdasarkan latar belakang di atas peneliti tertarik untuk membuat judul penelitian "Hubungan Penggunaan Backpack dan Posisi Duduk Terhadap Keluhan Nyeri Punggung Pada Anak Usia Sekolah".

\section{METODE PENELITIAN}

Penelitian ini menggunakan jenis penelitian kuantitatif dengan desain deskriptif korelasi dan pendekatan cross-sectional. Sampel pada penelitian ini ialah 121 anak 
usia sekolah di SD Negeri 111 Kota Pekanbaru, dengan kriteria inklusi sebagai berikut:

1) Siswa yang bersedia menjadi responden.

2) Siswa yang hadir saat penelitian dilakukan.

3) Siswa yang menggunakan tas backpack.

4) Siswa perempuan yang tidak sedang menstruasi.

Penelitian ini sudah dilakukan uji etik di Komite Etik STIKes Hang Tuah Pekanbaru dengan nomor surat 20/KEPK/STIKesHTP/IV/2019. Teknik sampling yang digunakan adalah stratified random sampling. Pengumpulan data menggunakan kuisioner penggunaan backpack dan lembar observasi REBA (Rapid Entire Body Assesment). Penelitian ini menggunakan analisis univariat dan bivariate, dengan nilai $r=0,367$, dan 0.503. Tujuan dari penelitian ini adalah mengetahui hubungan penggunaan backpack dan posisi duduk terhadap keluhan nyeri punggung pada anak usia sekolah.

\section{HASIL PENELITIAN}

\section{ANALISIS UNIVARIAT}

\section{A. Karakteristik responden}

Tabel 1

Karakteristik responden berdasarkan usia, jenis kelamin, kelas, dan berat backpack Siswa SD Negeri 111 Kota Pekanbaru tahun 2019

\begin{tabular}{clcc}
\hline No & Karakteristik responden & f & \% \\
\hline 1 & Jenis kelamin & & \\
& Perempuan & 55 & $45,5 \%$ \\
& Laki-laki & 66 & $54,5 \%$ \\
\hline 2 & Kelas & & \\
& Kelas 4 & 65 & $53,7 \%$ \\
& Kelas 5 & 56 & $46,3 \%$ \\
\hline 3 & Berat Backpack & & \\
& $\leq 10 \%$ Indeks Massa Tubuh & 17 & $14,0 \%$ \\
& $\geq 10 \%$ Indeks Massa Tubuh & 104 & $86,0 \%$ \\
\hline & Jumlah & 121 & $100 \%$ \\
\hline & & &
\end{tabular}

Berdasarkan Tabel 1 diatas dapat diketahui bahwa dari 121 responden, sebagian besar responden berjenis kelamin laki-laki berjumlah 66 siswa $(54,5 \%)$, sebagian besar responden berada di kelas 4 sejumlah 65 siswa $(53,7 \%)$, dan berat backpack siswa diketahui sebagian besar $\geq 10 \%$ Indeks Massa Tubuh yaitu berjumlah 104 siswa $(86,0 \%)$.

\section{B. Usia responden}

Tabel 2

Karakteristik responden berdasarkan usia siswa sd negeri 111 kota pekanbaru tahun 2019

\begin{tabular}{ccccccc}
\hline usia & $\mathrm{n}$ & mean & median & $\mathrm{SD}$ & min & maks \\
\hline usia & 121 & 10,31 & 10,00 & 0,646 & 9 & 11 \\
\hline
\end{tabular}

Berdasarkan data pada tabel 2 dapat diketahui bahwa nilai tengah atau median dari usia responden adalah 10, dengan usia minimum responden 9 tahun dan usia maksimum 10 tahun.

\section{Penggunaan backpack}

Tabel 3

Distribusi frekuensi penggunaan backpack

\begin{tabular}{lcc}
\hline \multicolumn{1}{c}{ Penggunaan Backpack } & f & $\%$ \\
\hline Sesuai & 31 & $25,6 \%$ \\
Tidak sesuai & 90 & $74,4 \%$ \\
\hline Jumlah & 121 & $100 \%$ \\
\hline
\end{tabular}


Chyntia Utami, Abdurrahman Hamid, Yecy Anggreny, Hubungan Penggunaan Backpack dan Posisi Duduk terhadap Keluhan Nyeri Punggung pada Anak Usia Sekolah

Dari tabel 3 di atas dapat diketahui bahwa dari 121 responden, sebanyak 31 siswa $(25,6 \%)$ menggunakan backpack dengan cara yang sesuai, dan sebanyak 90 siswa $(74,4 \%)$ tidak sesuai dalam menggunakan backpack.

\section{Posisi Duduk}

Tabel 4

Distribusi frekuensi posisi duduk

\begin{tabular}{lcc}
\hline \multicolumn{1}{c}{ Posisi Duduk } & f & \% \\
\hline Kurang ergonomis & 72 & $59,5 \%$ \\
Tidak ergonomis & 49 & $40,5 \%$ \\
\hline Jumlah & 121 & $100 \%$ \\
\hline
\end{tabular}

Tabel 4 di atas menunjukkan bahwa siswa dengan posisi duduk yang kurang ergonomis berjumlah 72 siswa $(59,5 \%)$, dan siswa dengan posisi duduk yang tidak ergonomis berjumlah 49 siswa $(40,5 \%)$.

\section{E. Keluhan Nyeri Punggung}

Tabel 5

Distribusi frekuensi keluhan nyeri punggung

\begin{tabular}{lcc}
\hline \multicolumn{1}{c}{ Keluhan Nyeri Punggung } & f & \% \\
\hline Tidak nyeri & 16 & $13,2 \%$ \\
Nyeri ringan & 97 & $80,2 \%$ \\
Nyeri sedang & 7 & $5,8 \%$ \\
Nyeri berat & 1 & $0,8 \%$ \\
\hline Jumlah & 121 & $100 \%$ \\
\hline
\end{tabular}

Dari tabel 5 di atas diketahui bahwa sebagian besar siswa mengeluh nyeri ringan sebanyak 97 siswa $(80,2 \%)$, tidak nyeri sebanyak 16 siswa $(13,2 \%)$, nyeri sedang sejumlah 7 siswa $(5,8 \%)$, dan 1 siswa $(0,8 \%)$ mengeluhkan nyeri berat.

\section{Analisis Bivariat}

\section{A. Hubungan penggunaan backpack dengan keluhan nyeri punggung.}

Tabel 6

Hubungan penggunaan backpack dengan keluhan nyeri punggung pada anak usia sekolah di SDN 111 Kota Pekanbaru tahun 2019

\begin{tabular}{|c|c|c|c|c|c|c|c|c|c|c|c|}
\hline \multirow{3}{*}{$\begin{array}{l}\text { Penggunaan } \\
\text { backpack }\end{array}$} & \multicolumn{8}{|c|}{ Keluhan nyeri punggung } & \multirow{2}{*}{\multicolumn{2}{|c|}{ Total }} & \multirow{3}{*}{$P$ value } \\
\hline & \multicolumn{2}{|c|}{$\begin{array}{l}\text { Tidak } \\
\text { nyeri }\end{array}$} & \multicolumn{2}{|c|}{ Nyeri ringan } & \multicolumn{2}{|c|}{ Nyeri sedang } & \multicolumn{2}{|c|}{ Nyeri berat } & & & \\
\hline & $\mathrm{N}$ & $\%$ & $\mathrm{~N}$ & $\%$ & $\mathrm{~N}$ & $\%$ & $\mathrm{~N}$ & $\%$ & $\mathrm{~N}$ & $\%$ & \\
\hline Sesuai & 9 & 29,0 & 19 & 61,3 & 3 & 9,7 & 0 & 0 & 31 & 100 & 0,011 \\
\hline Tidak sesuai & 7 & 7,8 & 78 & 86,7 & 4 & 4,4 & 1 & 1,1 & 90 & 100 & \\
\hline
\end{tabular}

Dari tabel 6 diatas, hasil uji Pearson Chi-Square menunjukkan bahwa $P$ value $<0,05$. Dari nilai tersebut dapat disimpulkan bahwa ada hubungan antara penggunaan backpack dengan keluhan nyeri punggung pada anak usia sekolah.

\section{B. Hubungan posisi duduk dengan keluhan nyeri punggung}

Tabel 7

Hubungan posisi duduk dengan keluhan nyeri punggung pada anak usia sekolah di SDN 111 Kota Pekanbaru tahun 2019 


\begin{tabular}{|c|c|c|c|c|c|c|c|c|c|c|c|}
\hline \multirow{3}{*}{ Posisi duduk } & \multicolumn{8}{|c|}{ Keluhan nyeri punggung } & & & \multirow{3}{*}{$P$ value } \\
\hline & \multicolumn{2}{|c|}{ Tidak nyeri } & \multicolumn{2}{|c|}{$\begin{array}{l}\text { Nyeri } \\
\text { ringan }\end{array}$} & \multicolumn{2}{|c|}{$\begin{array}{l}\text { Nyeri } \\
\text { sedang }\end{array}$} & \multicolumn{2}{|c|}{$\begin{array}{l}\text { Nyeri } \\
\text { berat }\end{array}$} & \multicolumn{2}{|c|}{ Total } & \\
\hline & $\mathrm{N}$ & $\%$ & $\mathrm{~N}$ & $\%$ & $\mathrm{~N}$ & $\%$ & $\mathrm{~N}$ & $\%$ & $\mathrm{~N}$ & $\%$ & \\
\hline $\begin{array}{l}\text { Kurang } \\
\text { ergonomis }\end{array}$ & 12 & 16,7 & 58 & 80,6 & 1 & 1,4 & 1 & 1,4 & 72 & 100 & 0,042 \\
\hline Tidak ergonomis & 4 & 8,2 & 39 & 79,6 & 6 & 12,2 & 0 & 0,4 & 49 & 100 & \\
\hline
\end{tabular}

Dari hasil uji Pearson Chi-Square yang di tampilkan pada tabel 7 diatas, diketahui $P$ value $<0,05$, yang berarti bahwa ada hubungan antara posisi duduk dengan keluhan nyeri punggung pada anak usia sekolah.

\section{PEMBAHASAN}

\section{A. Karakteristik responden}

Usia

Penelitian yang dilakukan oleh Lisanti, Martini, dan Widjasena (2018), mengemukakan bahwa umur memiliki kontribusi terhadap persepsi nyeri yang dirasakan, karena anak usia sekolah (6-12 tahun) sudah memiliki kemampuan untuk memberikan gambaran mengenai penyebab, jenis, kualitas nyeri, dan sudah mampu untuk menilai tingkat keparahan nyeri yang dirasakan. Berdasarkan kondisi kognitif tersebut, penliaian self-report terhadap nyeri dapat dirasakan pada anak usia sekolah.

\section{Jenis kelamin}

Sejalan dengan penelitian yang dilakukan oleh Legiran, Suciati, dan Pratiwi (2018) yang mengatakan bahwa jenis kelamin mempengaruhi kemampuan otot seseorang. Secara fisiologis, laki-laki memiliki kemampuan otot yang lebih besar jika dibandingkan dengan perempuan. Kekuatan otot perempuan rata-rata kurang lebih $60 \%$ dari kekuatan otot laki-laki, terutama pada punggung, lengan, dan kaki. Dari penjelasan diatas, dapat disimpulkan bahwa jenis kelamin memiliki pengaruh terhadap nyeri otot yang dirasakan oleh anak usia sekolah.

\section{Berat Backpack}

Penelitian yang dilakukan oleh Mahendrayani, Purnawati, dan Andayani (2016) mengemukakan bahwa anak dengan usia yang masih dalam masa pertumbuhan lebih beresiko untuk mengalami nyeri punggung akibat membawa tas yang berat dibandingkan dengan orang dewasa. Pernyataan ini diperkuat dengan penelitian yang dilakukan oleh Lisa (2018), menyatakan bahwa penggunaan tas punggung yang terlalu berat setiap hari dan berulang menjadi suatu faktor yang meningkatkan stress pada tulang belakang. Penekanan pada diskus tulang belakang, dan kurangnya pasokan darah ke 
Chyntia Utami, Abdurrahman Hamid, Yecy Anggreny, Hubungan Penggunaan Backpack dan Posisi Duduk terhadap Keluhan Nyeri Punggung pada Anak Usia Sekolah

otot tulang belakang akibat dari penekanan tas yang berat. Beberapa penjelasan di atas diyakini menjadi pencetus utama terjadinya nyeri punggung akibat tas yang terlalu berat.

\section{A. Hubungan penggunaan backpack dengan}

\section{keluhan nyeri punggung}

Berdasarkan hasil penelitian yang dilakukan oleh peneliti di SD Negeri 111 Kota pekanbaru dengan responden yang berpartisipasi berjumlah 121 orang menunjukkan hasil bahwa $P$ value dari uji Pearson Chi-Square <0.05. Sehingga, dapat disimpulkan bahwa hipotesis diterima $(\mathrm{Ha})$ yaitu terdapat hubungan antara penggunaan backpack dengan keluhan nyeri punggung.

Hasil pada penelitian ini sejalan dengan penelitian yang dilakukan oleh Lisanti, Martini, dan Widjasena (2018) dengan P value $=0,006(<0,05)$, yang berarti bahwa ada hubungan yang signifikan antara cara membawa tas dengan keluhan muskuloskeletal, diketahui bahwa membawa tas dengan ketidakseimbangan antara beban yang dibawa di bahu kanan dan kiri mampu menjadi pencetus keluhan nyeri punggung pada anak usia sekolah. Penelitian lain yang dilakukan oleh Fathoni (2013) menyimpulkan bahwa ada hubungan antara pemakaian backpack dengan keluhan nyeri punggung pada anak usia sekolah. Hal ini sesuai dengan teori yang menyebutkan membawa backpack yang lebih dari $10 \%$ IMT, cara penyusunan barang di dalam backpack yang tidak tepat, cara pemilihan dan cara penggunaan backpack yang tidak sesuai disimpulkan dapat menjadi pencetus dari timbulnya keluhan nyeri punggung (The American Ocupational Therapy Association, 2017).

Pada penelitian ini, dijumpai bahwa $86,0 \%$ anak memiliki ukuran berat backpack yang lebih dari 10\% Indeks Massa Tubuh anak. Peneliti menemukan bahwa sebagian besar anak membawa seluruh buku pelajaran mereka di dalam tas backpack yang digunakan, sehingga dapat diketahui bahwa hal tersebut lah yang menjadi penyebab backpack yang dibawa anak terlalu berat. Salah seorang responden juga menyebutkan bahwa bahu kanan dan kiri memerah dan terasa nyeri akibat tas yang digunakan tidak beralaskan busa, hanya berupa tali kain biasa. Studi penelitian yang dilakukan oleh Rai dan Argawal (2013) menyebutkan bahwa keluhan nyeri punggung pada anak usia sekolah sebagian besar disebabkan oleh ketegangan otot leher, bahu, dan punggung. Hal ini didukung oleh teori yang menyebutkan bahwa salah satu masalah kesehatan yang sering dialami oleh anak usia sekolah ialah ketegangan dan ketidakseimbangan otot (Wiarto, 2017). Pendapat tersebut didukung oleh teori yang menyebutkan bahwa anak usia sekolah memiliki perkembangan yang bersifat konsisten, namun fungsi otot pada anak usia sekolah belum mature jika dibandingkan ketika anak menginjak usia remaja, salah satu 
fungsi otot pada anak usia sekolah ialah menunjang aktivitas mereka seperti berlari, melompat, berjalan, dan termasuk membawa ransel yang berisi perlengkapan penunjang mereka untuk belajar setiap hari disekolah, sehingga apabila digunakan secara berlebihan mengakibatkan permasalahan pada muskuloskeletal terutama otot tulang belakang yang paling sering digunakan oleh anak usia sekolah (Bryant, 2019).

Pendapat di atas juga di perjelas dengan penelitian yang dilakukan oleh Lisanti, Martini, dan Widjasena (2018) bahwa penggunaan ransel dengan cara yang tidak sesuai menyebabkan tulang belakang bersandar ke sisi yang berlawanan, tulang punggung bagian tengah, tulang rusuk, dan tulang bagian bawah. Ketidakseimbangan ini menyebabkan ketegangan, kejang, dan nyeri pada otot punggung. Kondisi ini jika tidak di atasi dengan cepat menyebabkan prognosis pada otot punggung yang tidak baik.

Penelitian ini memberikan hasil bahwa penggunaan backpack yang tidak sesuai, sebagian besar mengalami nyeri yang sifatnya ringan hingga berat. Namun, jika dilihat kembali pada tabel 6, terdapat responden yang sudah sesuai dalam menggunakan backpack, namun masih merasa nyeri ringan dan nyeri sedang. Hal ini mungkin dipengaruhi oleh hal lain yang juga berpotensi menyebabkan nyeri punggung pada anak. Berdasarkan penelitian yang dilakukan oleh Dumandor, Angliadi, dan
Sengkey (2015) yang memberikan pernyataan bahwa di sisi lain, selain dari penggunaan backpack yang berat, faktor lain yang menjadi penyebab nyeri punggung pada anak ialah aktivitas fisik yang berat, status nutrisi yang lebih atau obesitas yang memberikan peningkatan beban yang harus ditopang oleh tulang belakang. Faktor lain yang juga dapat menjadi pencetus nyeri pada anak ialah faktor psikologis, seperti kecemasan, stress, dan depresi yang dapat menurunkan ambang rasa snyeri pada anak, akibatnya anak lebih mudah untuk merasakan ketidaknyamanan akibat nyeri.

Tata cara pemilihan backpack, cara menyusun barang di dalam backpack, dan cara penggunaan backpack merupakan hal yang sangat perlu diperhatikan oleh orangtua, juga pihak sekolah guna memberi dan mendukung pertumbuhan dan perkembangan yang terbaik untuk anak usia sekolah, terutama perkembangan biologis otot tulang belakang anak, agar tidak mengganggu aktivitas anak usia sekolah. Karena salah satu tugas perkembangan yang wajib dilalui oleh anak usia sekolah ialah kecakapan dan ketangkasan dalam aktivitas fisik

Penggunaan backpack mungkin dianggap sebagai hal yang tidak berpengaruh bagi anak usia sekolah yang masih dalam masa pertumbuhan. Maka dari itu, pengetahuan akan backpack safety atau tata cara penggunaan backpack yang benar harus menjadi hal yang 
Chyntia Utami, Abdurrahman Hamid, Yecy Anggreny, Hubungan Penggunaan Backpack dan Posisi Duduk terhadap Keluhan Nyeri Punggung pada Anak Usia Sekolah

di perhitungkan bagi orang tua dan pihak sekolah.

\section{B. Hubungan posisi duduk dengan keluhan nyeri punggung}

Dari hasil observasi yang dilakukan di SD Negeri 111 Kota Pekanbaru, dengan menggunakan uji statistic Pearson Chi-Square pada 121 responden didapatkan $P$ value 0,042 $(<0,05)$, sehingga dapat ditarik suatu kesimpulan bahwa tidak ada hubungan antara posisi duduk dengan keluhan nyeri punggung pada anak usia sekolah.

Hasil yang sama juga didapat oleh penelitian yang dilakukan oleh Syamsiah, Djojosugito, dan Argadireja (2017), bahwa ada hubungan antara posisi duduk dengan keluhan nyeri punggung. Penelitian lain oleh Grabiec, Snela, Rykala, Podgorska, dan Rachwal (2013) memberikan kesimpulan bahwa terdapat hubungan antara posisi duduk dengan keluhan nyeri punggung pada anak usia sekolah. Hal ini dibenarkan oleh penelitian yang menjelaskan bahwa duduk dengan posisi yang salah dalam waktu yang lama dapat meningkatkan jumlah energi yang dibutuhkan dalam beraktivitas, dengan posisi duduk yang salah mengakibatkan transfer tenaga dari otot ke jaringan rangka tidak efisien sehingga menyebabkan kelelahan pada sel otot rangka (Wahyuni, Winaya, Primayanti, 2016).

Terjadi penekanan berkepanjangan dan beban berlebihan yang dialami oleh leher dan punggung saat individu sedang duduk, ditambah waktu duduk yang lebih dari 10 detik mengakibatkan munculnya keluhan nyeri punggung (Andini, 2015). Semakin lama seseorang duduk dengan posisi yang tidak ergonomis, menyebabkan ketegangan otot di sekitar punggung dan ligamentum punggung akan meregang, terutama pada ligmentum yang ada pada Lumbal 2- Lumbal 5. Karena lapisan ligamentum pada lumbal 2-5 merupakan lapisan ligamentum paling tipis diantara lapisan ligament lainnya, sehingga lapisan ini sering mengalami iskemia yang menjadi penyebab timbulnya gangguan rasa nyaman yaitu nyeri (Padmiswari \& Griadhi, 2017). Selain dari itu, posisi duduk juga menyebabkan otot yang ada disekitar punggung mengalami kontraksi terus menerus dalam waktu yang lama, hal ini mengakibatkan terjepitnya pembuluh darah yang membawa pasokan oksigen ke jaringan otot, sehingga pembentukan energi dari $\mathrm{O}_{2}$ menjadi berkurang, sehingga terbentuklah asam laktat. Asam laktat merupakan salah satu gugus kimia yang menyebabkan otot menjadi mudah lelah, dan menimbulkan gangguan kenyamanan berupa nyeri pada otot yang tertekan akibat dari posisi duduk yang tidak ergonomis (Sumekar \& Natalia, 2010).

Berdasarkan penjelasan di atas, dapat disimpulkan bahwa, anak usia sekolah sebagian besar melakukan aktivitas dalam keadaan duduk. Mereka menghabiskan kurang lebih 5 jam di sekolah untuk belajar dalam 
posisi duduk, lalu melakukan kegiatan di rumah seperti bermain, menonton TV, dan membuat PR dalam posisi duduk. Sebagian besar indvidu termasuk anak usia sekolah memiliki posisi duduk yang tidak ergonomis karena kebiasaan yang menurut mereka tidak berpengaruh apa-apa pada kesehatan tulang belakang. Dalam kata lain, posisi duduk yang tidak ergonomis berbanding lurus dengan keluhan nyeri punggung yang dirasakan oleh anak usia sekolah.

Adapun keterbatasan pada penelitian ini adalah, transportasi responden menuju sekolah sudah terkaji. Namun, jarak antara sekolah dengan rumah, dan lama anak menyandang backpack tidak terkaji.

\section{SIMPULAN}

Dari hasil penelitian yang dilakukan di SD Negeri 111 Kota Pekanbaru, tentang hubungan penggunaan backpack dan posisi duduk terhadap keluhan nyeri punggung, dapat diambil beberapa kesimpulan sebagai berikut :

a. Dari 121 responden sebagian besar anak berusia 11 tahun, 66 orang responden berjenis kelamin laki-laki, dan sebagian besar responden berada di kelas 4 . Sebanyak 104 responden memiliki berat backpack yang lebih dari 10\% Indeks Massa Tubuh.

b. Terdapat hubungan yang signifikan antara penggunaan backpack dan keluhan nyeri punggung pada anak usia sekolah. c. Terdapat hubungan yang signifikan antara posisi duduk dengan keluhan nyeri punggung pada anak usia sekolah.

\section{SARAN}

a. Bagi tempat penelitian

Peneliti berharap bahwa penelitian ini dapat menjadi salah satu sumber informasi bagi tenaga pendidikan, guna menumbuhkan perhatian dan kesadaran terhadap kesehatan otot dan tulang anak usia sekolah sebagai upaya preventif terhadap munculnya keluhan nyeri punggung. Peneliti juga berharap, penelitian ini dapat terus menjadi upaya promotif dari sekolah kepada orang tua dan murid, akan pentingnya memperhatikan tata cara penggunaan backpack dan keergonomisan posisi duduk anak saat belajar dirumah maupun disekolah.

b. Bagi Dinas Pendidikan

Penelitian ini diharapkan dapat menjadi data primer dan informasi, juga sebagai pertimbangan bagi institusi pendidikan untuk memberikan sarana dan prasarana yang memadai bagi sekolah, seperti penyediaan loker di setiap kelas, dan penyediaan kursi serta meja belajar ergonomis di dalam kelas. Dinas pendidikan juga dapat mempertimbangkan untuk membuat kebijakan mengenai penggunaan backpack di setiap sekolah.

c. Bagi orang tua 
Chyntia Utami, Abdurrahman Hamid, Yecy Anggreny, Hubungan Penggunaan Backpack dan Posisi Duduk terhadap Keluhan Nyeri Punggung pada Anak Usia Sekolah

Sebagai informasi dan edukasi dalam menambah wawasan orang tua dalam peran sebagai pencegah primer terjadinya nyeri punggung pada anak akibat dari penggunaan backpack dan posisi duduk yang tidak sesuai, karena orang tua memiliki pengaruh yang besar terhadap perilaku, kebiasaan, dan sikap anak.

d. Bagi ilmu keperawatan

Penelitian ini dapat berkontribusi terkait keluhan nyeri punggung pada anak usia sekolah akibat dari penggunaan backpack dan posisi duduk. Khusunya, bagi perawat komunitas yang berkesempatan untuk pengembangan strategi dan metode yang atraktif serta efektif dalam mencegah nyeri punggung pada anak usia sekolah akibat dari penggunaan backpack dan posisi duduk.

e. Bagi Dinas Kesehatan dan Puskesmas

Penelitian ini dapat menjadi bahan masukkan bahwasannya pemeriksaan terhadap adanya keluhan nyeri punggung wajib untuk dilakukan, guna mencegah bertambahnya angka kejadian keluhan nyeri punggung pada anak sekolah yang masih dalam masa pertumbuhan.

f. Bagi peneliti selanjutnya

Penelitian ini diharapkan dapat menjadi informasi bagi peneliti selanjutnya. Diharapkan peneliti yang tertarik untuk melanjutkan penelitian ini, mungkin dapat menggunakan jenis penelitian yang berbeda, atau dapat meneliti mengenai factor-faktor yang mempengaruhi penggunaan backpack dan posisi duduk terhadap keluhan nyeri punggung dengan kategori umur responden yang berbeda.

\section{DAFTAR PUSTAKA}

Asriwati. (2017). Fisika kesehatan dalam keperawatan. Yogyakarta: Deepublish. Allghamdi, R.S., Nafee, H.M., El-Sayed, A \& Alsaadi, S.M. (2018). A Study of School Bag Weight and Back Pain Among Intermediate Female Students in Dammam City, King of Saudi Arabia. Journal of Nursing Education and Practice, 8(12), 105-111.DOI: 10.5430Ijnep.v8n12P105.

American Academy of Orthopedic Surgeons. (2015). Back Pain In Children. Diperoleh dari https://orthoinfo.aaos.org/en/diseasesconditions/back-pain-in-children.

Andini. F. (2015). Risk Factors Of Low Back Pain In Workers. J majority. 4(32), 1219.

http://juke.kedokteran.unila.ac.id/index .php.

Australian Institute of Health and Welfare. (2016).Impacts of Chronic Back Problems., hlm.115.https://www.aihw.gov.au/reports/art hritis-other-musculosceletalconditions/impacts-of-chronic-backproblems/contents/summary.

Azabagic, S., Spahic, R., Pranjic, N \& Mulic, M. (2016). Epidemiology of Muskuloskeletal Disorders In Primary School Children In Bosnia and Herzegovina. Mater Sociomed, 28 (3), 164-167. DOI: 10.5455/msm.2016.28.164-167.

Bellinger, T \& Jhonson, B. (2016). Don't Sit Still: Promoting Back Health While Seated. Haworth. hlm 1-7. 
Bryant. S. (2019). Muscular Development In Children.

https://study.com/academy/lesson/musc ular-developement-in-children.html.

Departemen Kesehatan Indonesia. (2009). Profil Kesehatan Indonesia 2008. Jakarta: Depkes.

Dumandor. S.V., Angliadi. E \& Sengkey. L. (2015). Hubungan Pengunaan Ransel Dengan Nyeri Punggung dan Kelainan Bentuk Tulang Belakang Pada Siswa Di SMP Negeri 2 Tombatu. Jurnal eclicic (eCI), 3(1), 243-247. https://ejournal.unsrat.ac.id/index.php/e clinic/download/6824/6384.

Fathoni. F. D. (2013). Hubungan Pemakaian Backpack Dengan Terjadinya nyeri Muskuloskeletal Pada Anak Usia 8-12 Tahun di SDN 2 Bener Sragen.[Skripsi]. Surakarta: Universitas Muhammadiyah Surakarta.

Grabiec. J.D., Snela.S., Rykala.J., Podgorska.J. \& Rachwal.M. (2013). Effects Of The Sitting Position On The Body Posture Of Children Aged 11 to 13 Years. IOS Press, 16(48), 1-8. DOI: 10.3233/WOR.141901.

Haerunisa, D., Taftazani, B.M \& Apsari, N.C. (2015). Pemenuhan Kebutuhan Dasar Anak Oleh Panti Sosial Asuhan Anak (PSAA). Prosding KS, 2(1), 1-146. http://jurnal.unpad.ac.id/prosiding/artic le/view/13232/6076.

Kementerian Pendidikan dan Kebudayaan Statistik Sekolah Dasar. (2017). Jakarta: Pusat Data dan Statistik Pendidikan dan Kebudayaan.

Khumaerah, A. (2011). Hubungan Antara Lama Duduk dan Posisi Duduk dengan Derajat Nyeri Pada Pekerja Jasa Pengetikan yang Menderita Nyeri Punggung Bawah Di Makassar 2011 [Skripsi]. Makassar: Universitas Hasanuddin.

Kozier, B., Erb, G., Berman, A \& Snyder, S.J. (Ed).(2011). Buku ajar fundamental keperawatan: Konsep, Proses, \& Praktik. Jakarta: EGC.

Kurniawidjaja. M. (2010). Teori dan Aplikasi Kesehatan Kerja. Jakarta: UI Press
Legiran., Suciati \& Pratiwi. (2018). Hubungan Antara Penggunaan Tas Sekolah dan Keluhan Muskuloskeletal Pada Siswa Sekolah Daar. JKK. 5(1), 1-9. https://download.garudarisetdikti.go.id/ article.php? article $=7997888 \mathrm{val}=5843 \&$ tittle=hubungan $\% 20$ antara $\% 20$ penggun a\%20tas\%20seklah\%20dan\%20\%20kel uhan\%20muskuloskeletal\%20pada $\% 20$ siswa\%20sekolahdasar\%20dasar.

Lisa. M. (2018). Hubungan Antara Berat Beban Tas Punggung Dengan Keluhan Nyeri Punggung Bawah, Nyeri Bahu, Dan Nyeri Leher Pada Siswa Di Madrasah Aliyah Negeri 2 Samarinda.[Skripsi].Kalimantan

Timur: Universitas Muhammadiyah Kalimantan.

Lisanti., Martini \& Widjasena. B. (2017). Hubungan Penggunaan Tas Punggung Dengan Keluhan Muskuloskeletal Pada Siswa MI Nashrul Fajar Meteseh Kecamatan Tembalang Kota Semarang. Jurnal Kesehatan Masyarakat. 5 (4), 409-417.

http://ejournal3.undip.ac.id/index.php/j $\mathrm{km}$.

Macedo, R.B., Silva, M.J., Sousa, N.F., Santos, J.V., Rodrigues, A.M \& Cumming, S.P. (2015). Quality of Life, School, and Non-Spesific Low Back Pain in Children and Adolescents. Journal de Pediatrica, 91(3), 263-269. http://dx.doi.org/10.1016/j.jped.201408.011 .

Mahendrayani. L. I., Purnawati. S \& Andayani. N. (2016). Hubungan Berat Tas Dengan Nyeri Punggung Bawah Pada Anak Usia Sekolah Umur 12-14 Tahun di Denpasar. https://ojs.unud.ac.id/index.php/mifi/art icle/view/13020/8710.

Nugraheni, H., Indarjo, S \& Suhat. (2018). Buku Ajar Promosi Kesehatan Berbasis Sekolah. Yogyakarta: Deepublish.

Padmiswari. N \& Griadhi. I. (2017). Hubungan Sikap Duduk Dan Lama Duduk Terhadap Keluhan Nyeri Punggung Bawah Pada Pengrajin Perak Di Desa Celuk Kecamatan Sukawati 
Chyntia Utami, Abdurrahman Hamid, Yecy Anggreny, Hubungan Penggunaan Backpack dan Posisi Duduk terhadap Keluhan Nyeri Punggung pada Anak Usia Sekolah

Kabupaten Gianyar. E-jurnal Medika. $6(2)$,

Https://ojs.unud.ac.id/index.php/eum/ar ticle/view/28963/17973.

Potter, P \& Perry, A.G.(2009). Fundamental keperawatan (Ed). Jakarta: EGC.

Rai, A \& Agarawal, S. (2013). Back Problems Due To Heavy Backpacks in School Children. IOSR Journal of Humanities And Social Science (IOSR-JHSS), 10(6). http://www.iosrjournals.org/iosrjhss/papers/Vol10-issue6/D1062226.

Sumekar. W.D \& Natalia. D. (2010). Computers Operator's Low Back Pain Caused By Sitting Position And Duration. $M K B$. 42(3), 123-127. DOI:http://dx.doi.org/10.15395/mkb.v4 2n3.23.

Syamsiah. I. R., Djojosugito. M. A \& Argadireja. D. S. (2017). Hubungan posisi duduk dan lama duduk dengan kejadian nyeri punggung pada pegawai administrasi Universitas Islam Bandung. Prosiding Pendidikan Dokter. 3(2), 339-345. http://karyailmiah.unisba.ac.id/index.ph p/dokter/article/view/8779/pdf.

The American Occupational Therapy Association. (2017). Backpack Strategies For Parents and Students. https://www.aota.org/AboutOccupational-Therapy/Patients-
Clients/ChildrenAndYouth/BackpackStrategies-Parents-Students.aspx.

United Nations Educational, Scientific, and Cultural Organization. (2019). UIS Statistics. Perancis: UNESCO.

Walker, J. (2012). Back Pain: Pathogenesis, Diagnosis, and Management. Nursing Standard/ RCN Publishing, 27(14), 4956. http://www.ncbi.nlm.nih.gov/Pubmed/2 3488026.

Wahyuni., Winaya. M. N \& Primayanti. I. (2016). Sikap duduk ergonomis mengurangi nyeri punggung bawah non spesifik pada mahasiswa program fisioterapi fakultas kedokteran udayana. Majalah Ilmiah Fisioterapi. 2(1), 15-18. https://ojs.unud.ac.id/index.php/rifi/arti cle/view/22061.

Wiarto, G. (2017). Nyeri tulang dan sendi. Yogyakarta: Goysen Publishing.

Wirth, B., Knecht, C \& Humphreys, K. (2013). Spine Day 2012: Spinal Pain in Swiss School Children, Epidemiology and Risk Factors. BMC Pediatrics, 13, 110.

http://www.biomedcentral.com/1421.2 431/13/159.

Wong, D.L., Hockenberry, M., Wilson, D., Winkelstein, M.L \& Schwantz, P. (2009). Buku ajar keperawatan pediatrik. Jakarta: EGC. 